\title{
Leukocyte Cell-Derived Chemotaxin 2 Retards Non-Small Cell Lung Cancer Progression Through Antagonizing MET and EGFR Activities
}

\author{
Wen-Yueh Hung ${ }^{\mathrm{a}, \mathrm{b}} \quad$ Jer-Hwa Chang ${ }^{\mathrm{b}, \mathrm{c}} \quad$ Yu Cheng ${ }^{\mathrm{a}}$ Chi-Kuan Chen ${ }^{\mathrm{d}}$ \\ Ji-Qing Chen ${ }^{e, f}$ Kuo-Tai Hua ${ }^{\mathrm{e}}$ Chao-Wen Cheng ${ }^{\mathrm{a}}$ Michael Hsiao ${ }^{\mathrm{d}}$

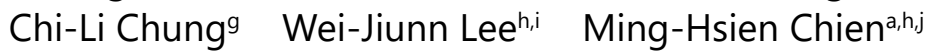

aGraduate Institute of Clinical Medicine, College of Medicine, Taipei Medical University, Taipei, ${ }^{b}$ Division of Pulmonary Medicine, Department of Internal Medicine, Wan Fang Hospital, Taipei Medical University, Taipei, 'Department of Internal Medicine, School of Medicine, College of Medicine, Taipei Medical University, Taipei, dGenomics Research Center, Academia Sinica, Taipei, e'Graduate Institute of Toxicology, College of Medicine, National Taiwan University, Taipei, Taiwan, ${ }^{\ddagger}$ Molecular and Cellular Biology Program, Dartmouth College, Hanover, USA, 9Division of Pulmonary Medicine, Department of Internal Medicine, Taipei Medical University Hospital, Taipei, hDepartment of Medical Education and Research, Wan Fang Hospital, Taipei Medical University, Taipei, 'Department of Urology, School of Medicine, Taipei Medical University, Taipei, jTMU Research Center of Cancer Translational Medicine, Taipei Medical University, Taipei, Taiwan

\section{Key Words}

LECT2 • EGFR • MET • Tumor growth • Tumor invasion • NSCLC

\begin{abstract}
Background/Aims: Epidermal growth factor receptor (EGFR)-tyrosine kinase inhibitor (TKI) therapy is a clinical option for non-small cell lung cancer (NSCLC) harboring activating EGFR mutations or for cancer with wild-type (WT) EGFR when chemotherapy has failed. MET receptor activation or MET gene amplification was reported to be a major mechanism of acquired resistance to EGFR-TKI therapy in NSCLC cells. Leukocyte cell-derived chemotaxin 2 (LECT2) is a multifunctional cytokine that was shown to suppress metastasis of hepatocellular carcinoma via inhibiting MET activity. Until now, the biological function responsible for LECT2's action in human NSCLC remains unclear. Methods: LECT2-knockout (KO) mice and NOD/SCID/IL2rynull (NSG) mice were respectively used to investigate the effects of LECT2 on the tumorigenicity and metastasis of murine (Lewis lung carcinoma, LLC) and human (HCC827) lung cancer cells. The effect of LECT2 on in vitro cell proliferation was evaluated, using MTS and colony formation assays. The effect of LECT2 on cell motility was evaluated using transwell migration and invasion assays. An enzyme-linked immunosorbent assay was performed to detect




\section{Cellular Physiology Cell Physiol Biochem 2018;51:337-355 and BiOChemistry Published \begin{tabular}{l|l} 
DOI: 10.1159/000495233 & (c) 2018 The Author(s). Published by S. Karger AG, Base \\
www.karger.com/cpb
\end{tabular}}

Hung et al.: LECT2 Retards NSCLC Progression via Targeting MET and EGFR

secreted LECT2 in plasma and media. Co-immunoprecipitation and Western blot assays were used to investigate the underlying mechanisms of LECT2 in NSCLC cells. Results: Compared to WT mice, mice with LECT2 deletion exhibited enhanced growth and metastasis of LLC cells, and survival times decreased in LLC-implanted mice. Overexpression of LECT2 in orthotopic human HCC827 xenografts in NSG mice resulted in significant inhibition of tumor growth and metastasis. In vitro, overexpression of LECT2 or treatment with a recombinant LECT2 protein impaired the colony-forming ability and motility of NSCLC cells (HCC827 and PC9) harboring high levels of activated EGFR and MET. Mechanistic investigations found that LECT2 bound to MET and EGFR to antagonize their activation and further suppress their common downstream pathways: phosphatidylinositol 3-kinase/Akt and extracellular signal-regulated kinase. Conclusion: EGFR-MET signaling is critical for aggressive behaviors of NSCLC and is recognized as a therapeutic target for NSCLC especially for patients with acquired resistance to EGFR-TKI therapy. Our findings demonstrate, for the first time, that LECT2 functions as a suppressor of the progression of NSCLC by targeting EGFR-MET signaling.

(C) 2018 The Author(s)

Published by S. Karger AG, Basel

\section{Introduction}

Non-small cell lung cancer (NSCLC) accounts about 80\% 85\% of all lung cancers and presents with different histological features, including squamous cell carcinoma, adenocarcinoma, and large cell carcinoma. The 5-year survival rate is as low as 15\% in NSCLC patients who present at an advanced stage [1,2]. Although chemotherapy only showed minor prolongation in survival compared to a sequential approach, it is still considered the standard approach for patients with advanced disease [3]. However, chemotherapy exhibits significant toxicity and can only be applied to a small subset of patients. The advent of novel therapies, such as epidermal growth factor receptor (EGFR)-tyrosine kinase inhibitors (TKIs) including gefitinib and erlotinib, has significantly prolonged the survival of NSCLC patients harboring EGFR mutations. It should be noted that even though most patients with EGFR mutations initially respond to TKI therapy, patients uniformly develop disease recurrence [4, 5]. In addition to the use in NSCLC patients with EGFR mutations, several clinical data also showed survival benefits of EGFR-TKI treatment for patients with wild-type (WT) EGFR and previously treated with chemotherapy but still developed advanced disease [6]. According to these observations, several guidelines also suggested that EGFR-TKIs be applied as secondline treatment for NSCLC patients harboring WT EGFR $[7,8]$.

Several mechanisms of EGFR-TKI resistance in NSCLC harboring activated EGFR mutations were described, such as a secondary EGFRT790M or C797S mutation, MET amplification, and hepatocyte growth factor (HGF) overexpression, and two major causes are the T790M mutation and MET amplification [4, 5,9]. MET is also a receptor tyrosine kinase (RTK) and showed dysregulated expression in many tumor types including lung, pancreatic, breast, renal, and gastric cancers [10] and shows high-affinity for HGF to mediate cell proliferation, invasion, migration, and survival [11]. Activation of MET is related to advanced cancer stages and worse patient survival [12] and induces acquired resistance to TKI therapy in NSCLC [13]. EGFR is trans-phosphorylated by MET and promotes survival of cells as heterodimerization partners of MET in lung cancer cells with MET amplification [14]. Moreover, HGF was reported to induce gefitinib resistance of lung adenocarcinomas with activated EGFR mutations or WT EGFR through the phosphatidylinositol-3 kinase (PI3K)/ Akt and extracellular signal-regulated kinase (ERK) pathways $[9,15]$. In current clinical trials, the addition of MET-TKIs to EGFR-TKIs can prolong survival or decrease metastasis in NSCLC patients with MET overexpression [16].

Leukocyte cell-derived chemotaxin 2 (LECT2) is mainly produced in the liver and was originally identified as a chemotactic factor for neutrophils [17]. Increasing evidence has shown that dysregulation of LECT2 is involved in many pathologic conditions, including renal amyloidosis [18], severe liver injury [19], and sepsis [20]. Recently, accumulating evidence indicated that LECT2 is not only a prognostic factor of liver cancer, but can also 


\section{Cellular Physiology Cell Physiol Biochem 2018;51:337-355

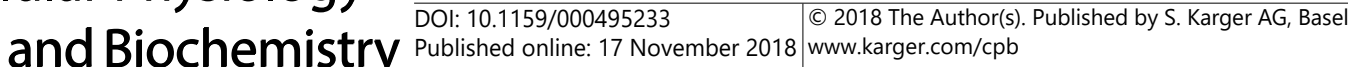

Hung et al.: LECT2 Retards NSCLC Progression via Targeting MET and EGFR

suppress the progression of hepatocellular carcinoma (HCC) [21, 22]. Chen et al. dissected the mechanisms involved in LECT2-mediated suppression of HCC and found that LECT2 directly binds to the MET receptor on the extracellular HxGxD motif and recruits protein tyrosine phosphatase 1B (PTP-1B) to inhibit MET activation [22]. Until now, the effects of LECT2 on other tumor types are largely unknown. Most recently, LECT2 was reported to be an important predictor for both breast carcinoma recurrence and mortality among smokers [23]. Herein, we evaluated the effect of secreted LECT2 on modulating the behaviors of NSCLC cells and found that LECT2 could be a potential suppressor of tumor progression of NSCLC cells by targeting both MET and EGFR and their common downstream pathways, Akt and ERK.

\section{Materials and Methods}

\section{Chemicals and reagents}

Gefitinib (Irresa) was purchased from Selleckchem (Houston, TX). The recombinant human HGF and murine HGF were purchased from R\&D Systems (Minneapolis, MN). Fetal bovine serum (FBS), antibiotics, molecular weight standards, trypsin-EDTA, trypan blue stain, and all medium additives were obtained from Life Technologies (Gaithersburg, MD). Antibodies specific for the unphosphorylated and corresponding phosphorylated (p-) forms of EGFR, MET, Akt, and EKR1/2 were purchased from Cell Signaling Technology (Danvers, MA). Anti-LECT2, anti- $\beta$-actin, and anti- $\alpha$-tubulin antibodies were purchased from Santa Cruz Biotechnology (Santa Cruz, CA). An anti-HA antibody and unless otherwise specified, other chemicals used in this study were purchased from Sigma (St. Louis, MO).

\section{Purification of recombinant LECT2}

To express human recombinant (hr)-LECT2 and murine recombinant (mr)-LECT2 proteins, plasmids were transfected into CHO-K1 cells for transient expression using the HyFect DNA transfection reagent (Leadgene Biomedical, Taiwan). In brief, $3 \times 10^{6}$ cells were seeded in T-75- $\mathrm{cm}^{2}$ flasks $16 \mathrm{~h}$ before transfection. For DNA transfection, each flask used $5 \mu \mathrm{g}$ of plasmids for transfection following instructions in the product information. Cells were continuously cultured in CD-CHO medium (Thermo Fisher Scientific) for $96 \mathrm{~h}$. Recombinant proteins in CD-CHO medium were purified using protein A agarose (Thermo Fisher Scientific) and dialysis in phosphate-buffered saline (PBS). Proteins were then filtered with a sterile $0.2-\mu \mathrm{m}$ polyethersulfone syringe filter and stored at $-20^{\circ} \mathrm{C}$ until use.

LECT2-knockout (KO) mice

LECT2-KO mice were produced as described previously [19] and kindly provided by Dr. Yamagoe (National Institute of Infectious Diseases, Tokyo, Japan). All experimental mice were generated from intercrosses between heterozygous mice in the National Laboratory Animal Center (Tainan, Taiwan), and littermates were divided into groups.

\section{Cell lines and cell culture}

The A549, H460, H1975, and HCC827 NSCLC cell lines were purchased from American Type Culture Collection (ATCC, Manassas, VA). PC9 cells were developed by Lee and colleagues at National Cancer Center Hospital (Tokyo, Japan) [24]. All NSCLC cells were maintained in RPMI 1640 supplemented with 10\% fetal bovine serum (FBS) and 1\% penicillin-streptomycin-glutamine. The 293T human embryonic kidney and mouse Lewis lung carcinoma (LLC) cell lines were also purchased from ATCC and maintained in Dulbecco's modified Eagle's medium (DMEM) supplemented with 10\% FBS and 1\% penicillin-streptomycin-glutamine. All cells were incubated at $37^{\circ} \mathrm{C}$ in a humidified $5 \% \mathrm{CO}_{2}$ atmosphere.

\section{Preparation of total cell extracts and Western blot analysis}

Protein lysates were prepared as described previously [25]. Equal amounts of protein extracts (20 30 $\mu \mathrm{g}$ ) were subjected to $10 \%$ or $12 \%$ sodium dodecylsulfate polyacrylamide gel electrophoresis (SDSPAGE) and blotted onto polyvinylidene fluoride membranes (Millipore, Belford, MA). After blocking, blots were incubated with primary antibodies in PBS containing Triton X-100 (PBST) for $1 \mathrm{~h}$ followed by two 


\section{Cellular Physiology Cell Physiol Biochem 2018;51:337-355

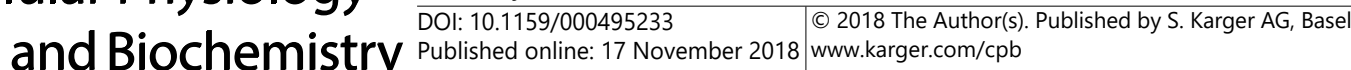

Hung et al.: LECT2 Retards NSCLC Progression via Targeting MET and EGFR

washes (for $15 \mathrm{~min}$ each) in PBST. Samples were then incubated with horseradish peroxidase-conjugated secondary antibodies for $30 \mathrm{~min}$. After washing, blots were incubated for $1 \mathrm{~min}$ with the enhanced chemiluminescent Western blotting reagent (Millipore, Billerica, MA), and chemiluminescence was detected by a chemiluminescence imaging system, MultiGel-21, (TOP BIO, New Taipei City, Taiwan) for 0.5 3 min. Furthermore, the same blots were stripped with stripping buffer (TOOLS, New Taipei City, Taiwan) and reprobed with $\beta$-actin or $\alpha$-tubulin antibodies as the internal control.

\section{Cell viability assay (MTS assay)}

Lung cancer cells $\left(5 \times 10^{3}\right)$ were seeded in 96-well plates, treated with $100 \mathrm{ng} / \mathrm{mL}$ recombinant LECT2 for different time points, and then subjected to a cell-viability assay (MTS assay; Promega, Madison, WI) according to the manufacturer's instructions.

\section{Transwell migration and invasion assays}

Cells $\left(3 \times 10^{4}\right)$ were plated in an uncoated top chamber (24-well insert; pore size, $8 \mu \mathrm{m}$; Corning Costar, Corning, NY) for the migration assay, while the invasion assay was performed in a top chamber coated with Matrigel (BD Biosciences, Bedford, MA). In these assays, LECT2-treated cells or LECT2-overexpressing cells were plated in serum-free medium, supplemented with serum or HGF (40 ng/ml), which was used as a chemoattractant in the lower chamber. After $24 \mathrm{~h}$ of incubation, cells on the lower surface of the membrane were fixed with methanol and stained with $0.2 \%$ crystal violet. The number of cells migrating through or invading through the membrane was counted under a light microscope $(\times 100$, three random fields per well).

\section{LECT2 measured by an enzyme-linked immunosorbent assay (ELISA)}

Cultured cancer cells $\left(6 \times 10^{6}\right.$ cells $/ 10-\mathrm{cm}$ plate $)$ were rinsed twice with PBS and cultured in $10 \mathrm{ml}$ of serum-free medium for 24 or $48 \mathrm{~h}$. Cancer cell conditioned medium (CM) was collected and clarified by centrifugation ( $5000 \mathrm{rpm}$ at $4{ }^{\circ} \mathrm{C}$ for $5 \mathrm{~min}$ ) to remove cell debris. Moreover, serum from LECT2-KO and WT mice were also collected. LECT2 levels in CM and serum were respectively determined with a human LECT2 ELISA kit (Cusabio Biotech, Wuhan, China) and a mouse LECT2 ELISA kit (MBL, Nagoya, Japan), according to the manufacturers' instructions.

\section{Lentiviral production and infection}

The lentiviral vector and its packaging vectors were transfected into 293T packaging cells by calcium phosphate transfection. Briefly, $10^{6} 293 \mathrm{~T}$ cells were subcultured on 10 -cm culture dishes overnight before transfection. Then, cells were transfected with $10 \mu \mathrm{g}$ pWPI-LECT2 or pWPI-control together with $10 \mu \mathrm{g}$ of pCMV $\Delta$ R8.91 (the packaging vector) and $1 \mu \mathrm{g}$ of pMD.G (the envelope vector). After $5 \mathrm{~h}$ of incubation, the transfection medium was replaced with fresh culture medium. After $48 \mathrm{~h}$, lentivirus-containing medium was collected from the transfection and spun down at $1500 \mathrm{rpm}$ for $5 \mathrm{~min}$ to pelletize the cell debris. The supernatant was then filtered through a $0.45-\mu \mathrm{m}$ filter, and target cells were infected with fresh lentiviruscontaining medium (supplemented with $8 \mu \mathrm{g} / \mathrm{ml}$ polybrene) for $24 \mathrm{~h}$ and subjected to different functional assays.

\section{Plate colony-formation assay}

WT or LECT-overexpressing NSCLC cells $\left(10^{3}\right)$ were seeded in six-well plates and incubated for $24 \mathrm{~h}$. Thereafter, the medium was changed every 2 days; 10 days later, cells were stained with crystal violet, and colonies with more than 50 cells were counted.

DNA transfection

All of the constructs were generated by standard protocols. The genes and/or their fragments, including LECT2, MET, and EGFR, were amplified by a PCR and cloned into the pCDNA3.1 vector (Invitrogen). Expression vectors were transiently transfected into test cells with the Lipofectamine 2000 transfection reagent. 


\section{Cellular Physiology Cell Physiol Biochem 2018;51:337-355 and Biochemistry Published \begin{tabular}{l|l} 
DOI: 10.1159/000495233 & $\begin{array}{l}\text { (c) } 2018 \text { The Author(s). Published by S. Karger AG, Basel } \\
\text { www.karger.com/cpb }\end{array}$
\end{tabular}}

Hung et al.: LECT2 Retards NSCLC Progression via Targeting MET and EGFR

\section{Immunoprecipitation (IP)}

293T cells were transfected with indicated plasmids and lysed on ice with IP lysis buffer (50 mM Tris [pH 7.4], $150 \mathrm{mM} \mathrm{NaCl}, 1 \%$ Triton X-100, and 1\% NP-40). Equal amounts of cell lysates were immunoprecipitated with an anti-hemoagglutinin (HA) antibody combined with protein A agarose beads. The collected protein complexes were washed four times with IP buffer and eluted by boiling with protein sample buffer under reducing conditions. Then, proteins were resolved by SDS-PAGE and analyzed by Western blotting with antibodies for MET, EGFR, HA, and LECT2.

\section{In vivo antitumor activity of LECT2}

Male NSG (NOD-scid IL2r $\gamma^{\text {null }}$ ) and LECT-KO mice were used for the orthotopic metastasis assays. Totals of $10^{6}$ and $5 \times 10^{5}$ luciferase-expressing human NSCLC cells (HCC827 and A549) and murine LLC cells were resuspended in a 1:1 mixture of PBS and Growth Factor-Reduced (GFR)-Matrigel. This mixture was then injected into the left lateral thorax of each NSG or LECT2-KO mouse. The tumor size and location were monitored and quantified with a noninvasive bioluminescence system (Xenogen IVIS-200 system, PerkinElmer, Waltham, MA). After 21 and 17 days, the HCC827-injected and LLC-injected mice were respectively sacrificed, and luciferase activities in the excised lungs were further determined using the IVIS200 system. Mouse lungs were also fixed, sectioned, and stained with hematoxylin and eosin (H\&E).

\section{Statistical analysis}

Data are presented as the mean \pm standard deviation (SD). Statistical analyses were performed using the Statistical Package for Social Science software, vers. 16 (SPSS, Chicago, IL). A non-parametric test was used for comparisons between two groups due to small sample size, i.e., The Median test was applied to examine the differences between group medians. Differences were considered significant at $p<0.05$. KaplanMeier nonparametric model plots were conducted and the log rank test was used to test the differences in the survival between wild-type and LECT2-KO mice injected with luciferase-expressing murine LLC cells. $p$ $<0.05$ was considered to represent a statistically significant difference.

\section{Results}

Genetic depletion of LECT2 promotes tumor progression and decreases the survival rate in an LLC orthotopic graft model

To evaluate the role of LECT2 in the progression of lung cancer in mice, systemic KO mice of LECT2 (LECT2 -/- mice) were used. No serum LECT2 was detected in LECT2 -/mice and around $54 \mathrm{ng} / \mathrm{ml}$ of LECT2 was detected in WT mice using an ELISA (Fig. 1A). Seventeen days after inoculation with luciferase-tagged LLC cells into the left lateral thorax, the tumorigenic ability had increased in LECT2 -/- mice compared to WT mice by photon emission detection in vivo (Fig. 1B). After the mice were sacrificed, ex vivo imaging of their lungs exhibited a higher photon intensity in LECT2 -/- mice compared to WT mice, in both orthotopic tumors (left lung) and metastatic tumors (right lung) (Fig. 1C). A parallel study in a different animal cohort was also performed and showed that LECT2 -/- mice with LLC tumors had significantly shorter survival times compared to WT mice with tumors (Fig. 1D). These results revealed that deletion of LECT2 enhances progression of murine lung tumors in mice and suggested that LECT2 functions as a circulating protein.

\section{mr-LECT2 suppresses migration and invasion of LLC cells by downregulating MET} activation

Previous studies indicated that MET is an important target of LECT2 to suppress HCC progression, and MET activation also plays a critical role in modulating NSCLC progression $[22,26]$. To determine whether the LECT2 protein interferes with MET activation and cell behaviors such as migration, invasion, and proliferation in LLC cells, we purified the mr-LECT2 protein and performed Western blot, migration/invasion, and MTS assays. The addition of murine HGF (40 ng/mL) to starvation medium significantly induced phosphorylation of MET and its downstream signals, Akt and ERK, and activation of the HGF/ 
A

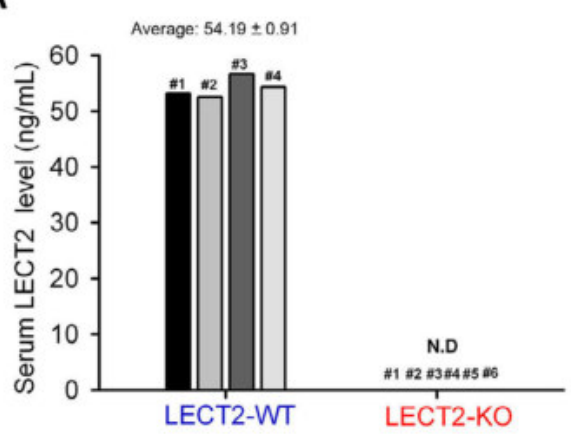

B
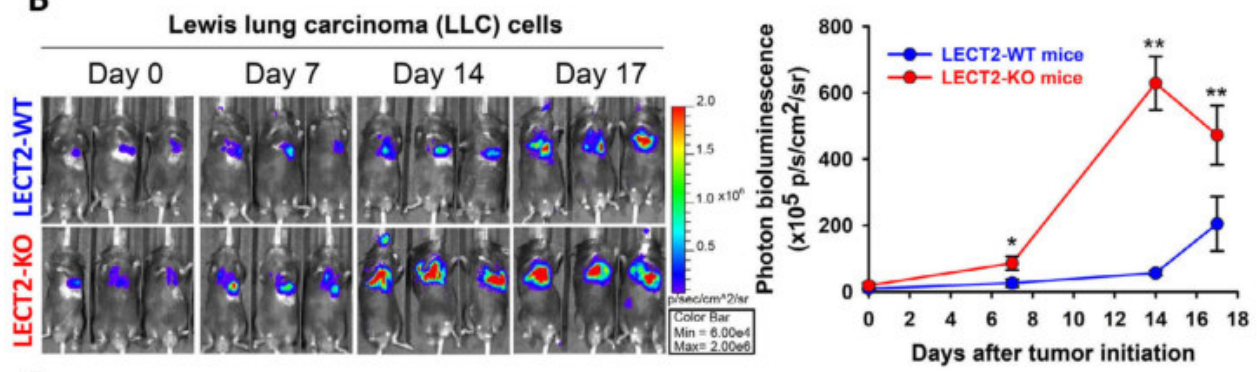

C
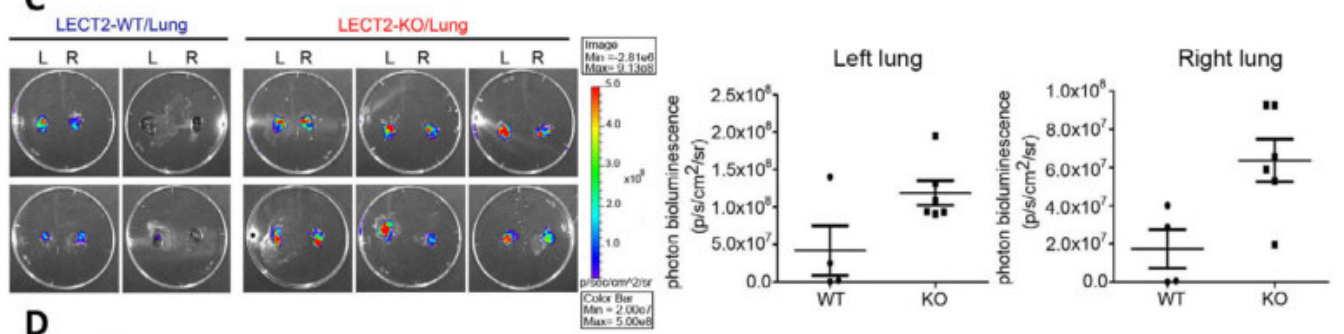

D

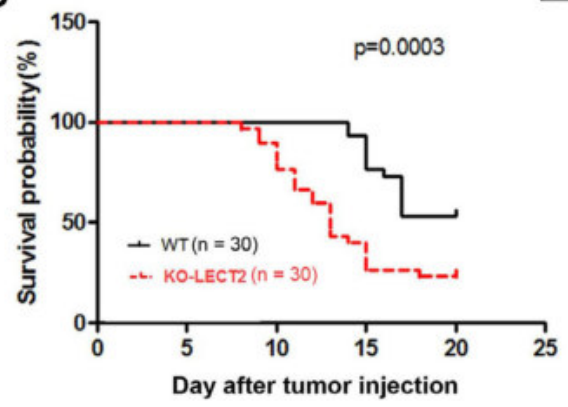

Fig. 1. Leukocyte cell-derived chemotaxin 2 (LECT2) deletion enhances tumor progression and decreases survival rates in mice with Lewis lung carcinoma (LLC) orthotopic grafts. (A) Serum levels of LECT2 in LECT-deficient and wild-type (WT) mice with implanted LLC tumors after 1 week. (B) Left panel, Xenogen IVIS spectrum bioluminescence images are shown with the orthotopic LLC tumor location and growth. A quantitative analysis of the Xenogen imaging signal intensity from tumor tissues on days $0,7,14$, and 17 after tumor implantation is shown in the right panel. ${ }^{*} \mathrm{p}<0.05,{ }^{* *} \mathrm{p}<0.01$ compared to the WT groups. (C) Lungs were isolated and examined at the end of this spontaneous metastasis assay. Left panel: Cancer metastasis from the left lung to the right lung was imaged with bioluminescence at the end of the study. Right panel: Signal intensities from primary tumors (left lung) and metastatic tumors (right lung) were bioluminescently captured at the end of the study, with the mean signal for each group indicated. (D) An overall survival curve was produced for WT and LECT2-depleted mice $(n=30)$ implanted with LLC tumors using the Kaplan-Meier method. p values were determined using a log-rank test. 
A

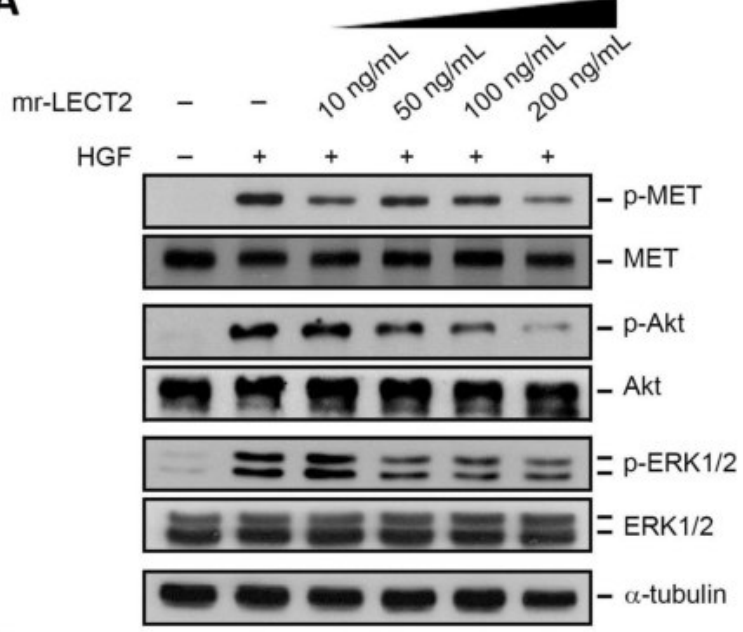

B

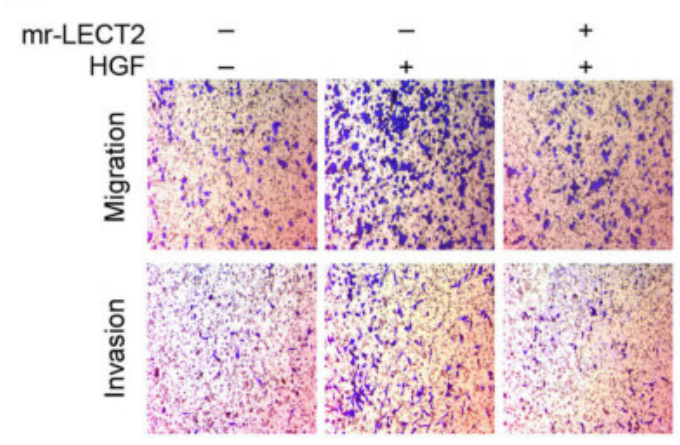

C

D
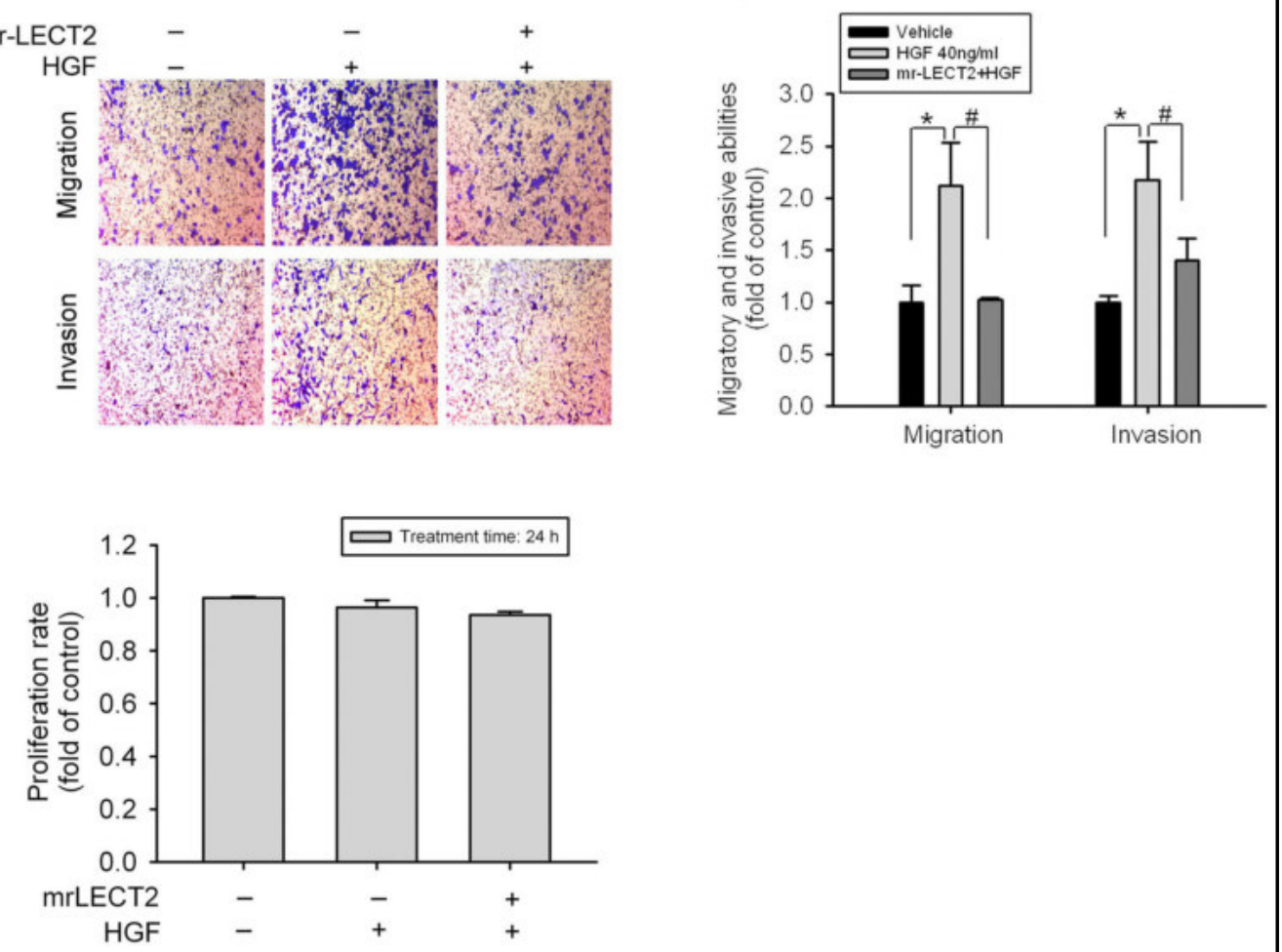

Fig. 2. Effect of murine recombinant (mr)-LECT2 on hepatocyte growth factor (HGF)-induced activation of MET, Akt, and extracellular signal-regulated kinase 1/2/ (ERK1/2) signals and cell motility in Lewis lung carcinoma (LLC) cells. (A) Serum-starved LLC cells were treated with HGF or cotreated with HGF and indicated concentrations of mr-LECT2 for $30 \mathrm{~min}$. Lysates were collected from cells and subjected to a Western blot analysis to detect phosphorylation levels of MET, Akt, and ERK1/2. (B-C) LLC cells were treated with $100 \mathrm{ng} / \mathrm{mL} \mathrm{mr}$-LECT2 with or without HGF for the transwell migration and Matrigel invasion assays (B). Results are expressed as multiples of the control. Data are expressed as the mean \pm SD of three independent experiments. * $\mathrm{p}<0.05$ compared to control group. ${ }^{\#} \mathrm{p}<0.05$ compared to the HGF treatmentonly group (C). (D) Proliferation rate of LLC cells seeded in a 96-well plate and treated with HGF (40 ng/ $\mathrm{mL}$ ) alone or combined with $100 \mathrm{ng} / \mathrm{mL}$ mr-LECT2 protein for $24 \mathrm{~h}$. Cell proliferation was measured with an MTS assay. 


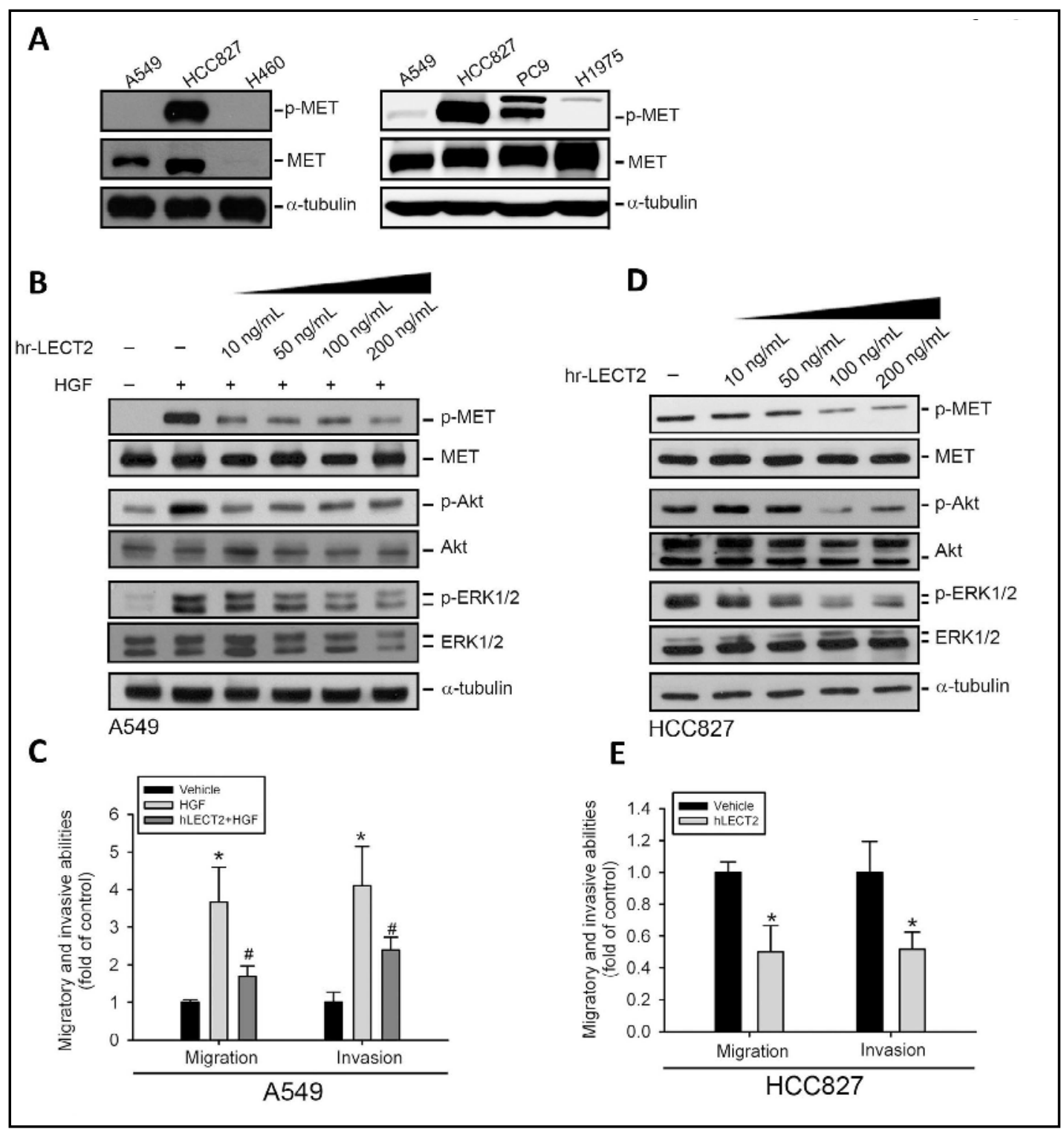

Fig. 3. Human recombinant (hr)-LECT2 inhibits the MET activation-mediated cell motility increase in human non-small cell lung cancer (NSCLC) cells harboring the wild-type (WT) and mutant epithelial growth factor receptor (EGFR). (A) Detection of protein levels of MET and p-MET by Western blotting in different NSCLC cell lines harboring the WT (A549 and H460) and mutant EGFR (HCC827, PC9, and H1975). (B, D) Serumstarved A549 cells were treated with various concentrations of hr-LECT2 with or without cotreatment with hepatocyte growth factor (HGF) (B), or HCC827 cells were only treated with various concentrations of hrLECT2 (D) for $30 \mathrm{~min}$, and a Western blot analysis was performed to detect phosphorylation of MET, Akt, and extracellular signal-regulated kinase 1/2 (ERK1/2) in both cells. (C, E) Effects of hr-LECT2 on HGFinduced motility in A549 cells (C) and the endogenous migratory and invasive activities in HCC827 cells (E) were measured by transwell migration and Matrigel invasion assays. Results are expressed as multiples of the control. Data are expressed as the mean \pm SD of three independent experiments. ${ }^{*} \mathrm{p}<0.05$ compared to the control group. ${ }^{\#} \mathrm{p}<0.05$ compared to the HGF treatment-only group.

MET axis was significantly suppressed by co-treatment with different concentrations of mrLECT2 (50 200 ng/mL) (Fig. 2A). Moreover, the HGF-induced increases in the migratory and invasive abilities of LLC cells were also significantly inhibited by treatment with the mr-LECT2 protein (Fig. 2B-C). Although previous studies indicated that HGF/MET signaling 


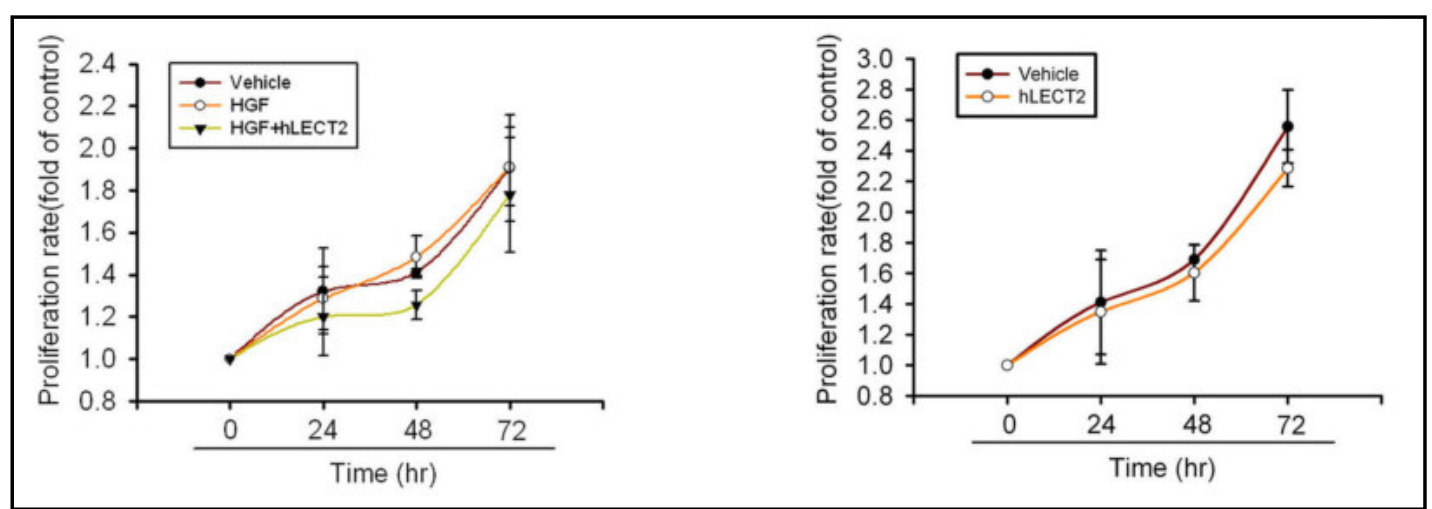

Fig. 4. Neither treatment with HGF or hr-LECT2 only, nor cotreatment with HGF and hr-LECT2 alters the proliferation rate of non-small cell lung cancer (NSCLC) cells. Proliferation rates of HCC827 and A549 cells seeded in a 96-well plate and treated with HGF, HGF + hr-LECT2, or hr-LECT2 as indicated for 24, 48, and 72 h. Cell proliferation was measured with the MTS assay.

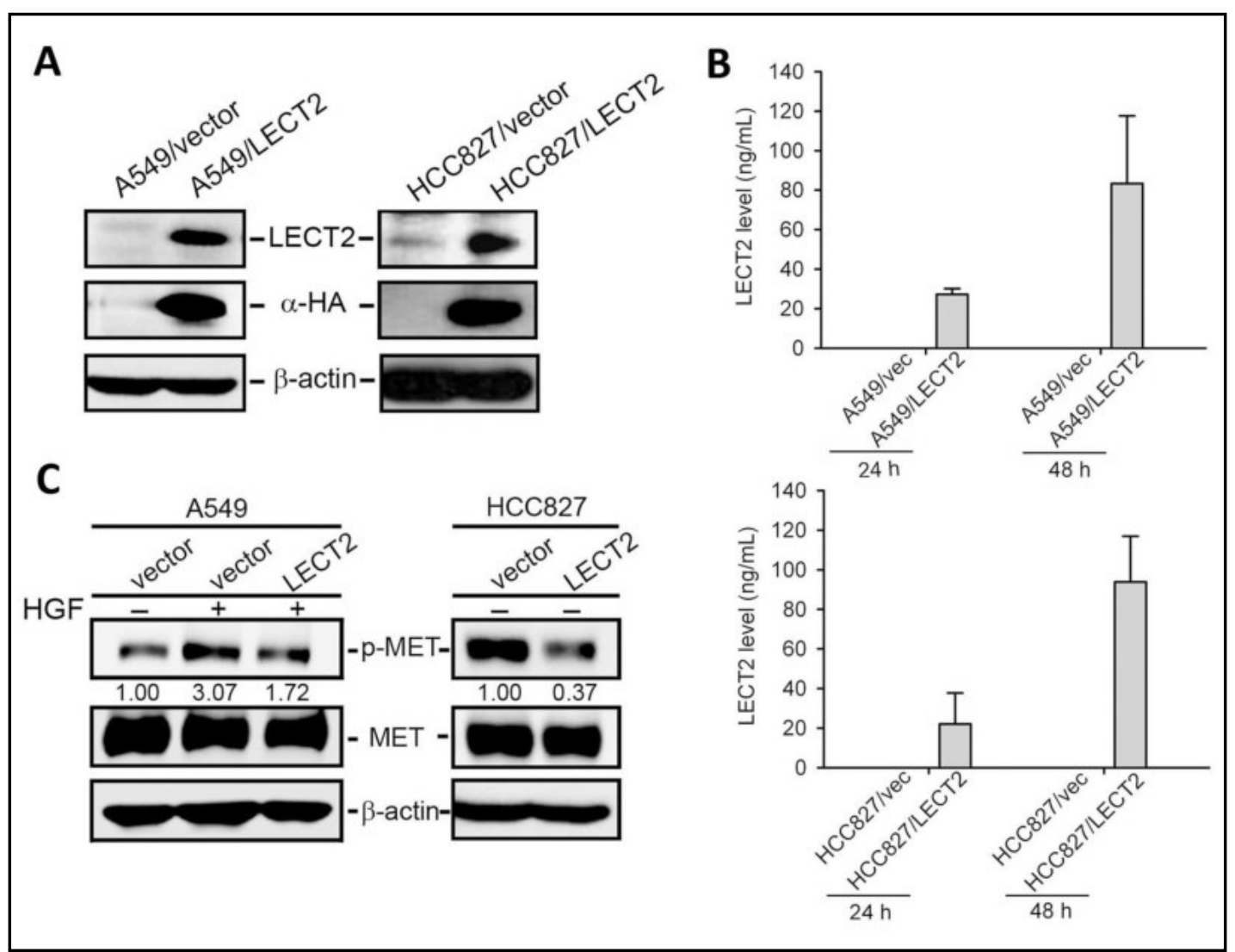

Fig. 5. Overexpression of LECT2 in human non-small cell lung cancer (NSCLC) cells inhibits MET activation. (A-B) LECT2 protein levels in A549 and HCC827 cells infected with a lentivirus carrying the control (A549/ vector and HCC827/vector) or hemoagglutinin (HA)-tagged LECT2 expression vector (A549/LECT2 and HCC827/LECT2). After 24 or $48 \mathrm{~h}$ of infection, cell lysates and conditioned medium were collected to measure LECT2 protein levels by Western blotting (A) and an ELISA (B), respectively. (C) Cell lysates from serum-starved A549/LECT2 and A549/vector cells which were treated with vehicle or hepatocyte growth factor (HGF) as indicated for $30 \mathrm{~min}$ or cell lysates from HCC827/LECT2 and HCC827/vector cells were all subjected to a Western blot analysis to detect MET activation. 


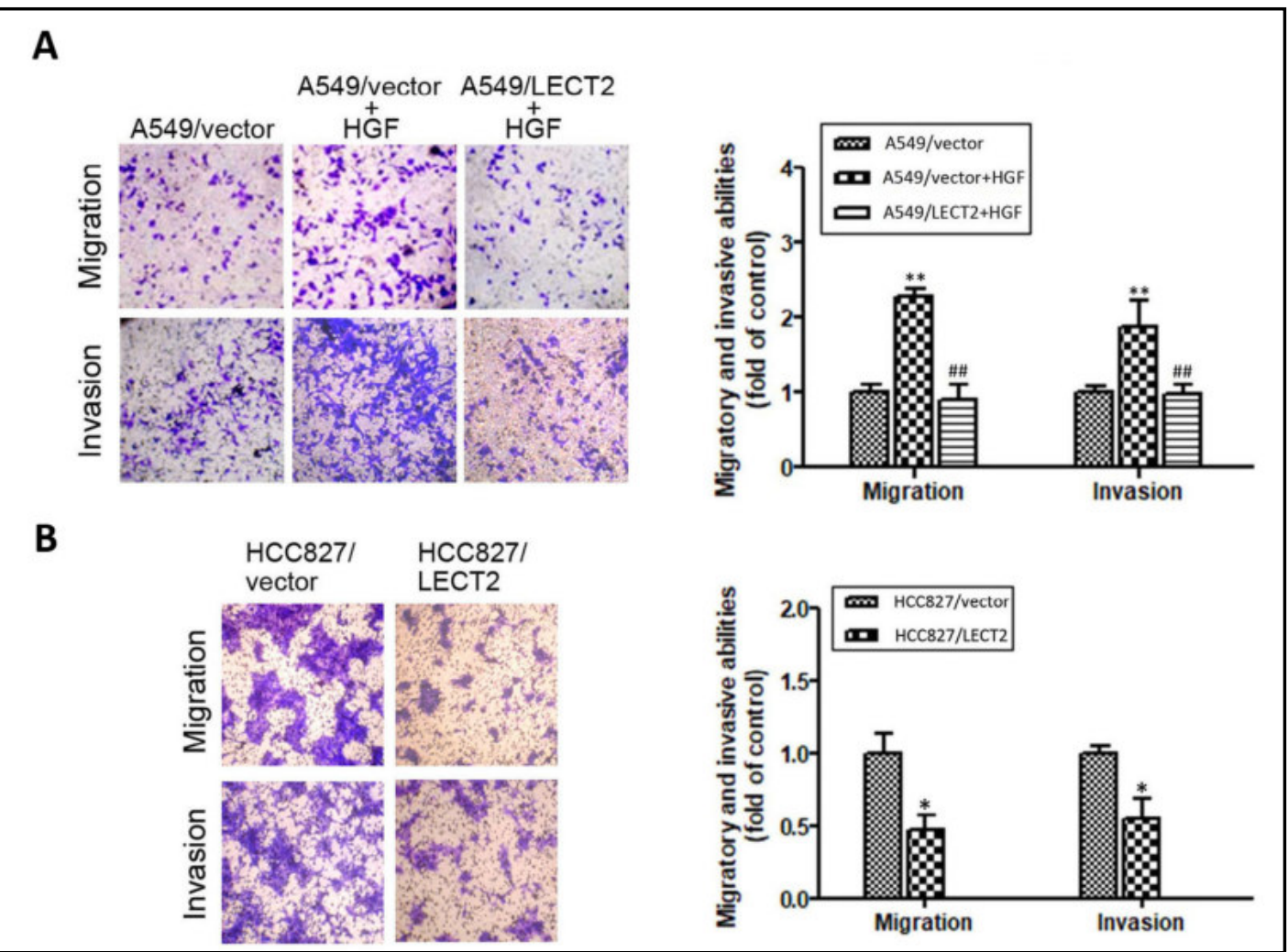

Fig. 6. Overexpression of LECT2 in human non-small cell lung cancer (NSCLC) cells suppresses their ability to migrate and invade in vitro. (A-B) A549/LECT2 and A549/vector cells with vehicle or HGF treatment (A) or HCC827/LECT2 and HCC827/vector cells with no treatment (B) were all subjected to transwell migration and Matrigel invasion assays. Results are expressed as multiples of the control. Data are expressed as the mean \pm SD of three independent experiments. ${ }^{*} \mathrm{p}<0.05$, ${ }^{* *} \mathrm{p}<0.01$ compared to the control group. ${ }^{\# \#} \mathrm{p}<0.01$ compared to the HGF treatment-only group.

can also promote the proliferation of lung cancer cells [26], our MTS results showed that treatment with HGF or HGF combined with mr-LECT2 for $24 \mathrm{~h}$ did not significantly alter the proliferation rate of LLC cells (Fig. 2D). These data suggested that the mr-LECT2 protein inhibits the motility of LLC possibly through suppressing the HGF/MET axis.

hr-LECT2 inhibits MET activation-induced cell motility of human NSCLC cells harboring the WT and activating mutant EGFR

To further confirm the inhibitory effect of LECT2 on MET activation-induced progression of human NSCLC cells, we first evaluated the endogenous protein expression and activation levels of MET in several human NSCLC cell lines harboring the WT (H460 and A549) or activating mutant EGFR (PC9, HCC827, and H1975). We found that A549, H1975, PC9, and HCC827 cells expressed higher levels of the MET protein compared to H460 cells. HCC827 and PC9 cells respectively showed high and moderate endogenous activation of MET (Fig. 3A). Therefore, the HCC827 and A549 cell lines were selected for subsequent in vitro and in vivo studies. Treatment of A549 with different concentrations of hr-LECT2 effectively suppressed the HGF-induced activation of MET, Akt, and ERK signaling (Fig. 3B) and increases in the migratory and invasive abilities (Fig. 3C). In the absence of HGF, we found that hr-LECT2 $(100 \sim 200 \mathrm{ng} / \mathrm{ml})$ still suppressed the endogenous activity of MET and the migratory and invasive abilities of HCC827 cells (Fig. 3D-E), suggesting that LECT2 inhibits MET-mediated cell motility possibly not through competing with HGF binding. Similar to LLC cells, Neither HGF or hr-LECT2 treatment only, nor cotreatment with HGF and hr-LECT2 altered the proliferation rate of A549 or HCC827 cells (Fig. 4). 
Overexpression of LECT2 in human A549 and HCC827 cells inhibited MET activation and their ability to migrate and invade in vitro

Due to the half-life of LECT2 protein $(16 \mathrm{kDa})$ is short, we further overexpressed LECT2 in A549 and HCC827 cells to examine the chronic action of LECT2, such as its anticancer effects in an in vivo model. Expression of endogenous LECT2 was negligible in A549 and HCC827 cells infected with the control vector (Fig. 5A-B). After infection with the LECT2 expression vector ( $\mathrm{pWPI-LECT2),} \mathrm{overexpressed} \mathrm{protein} \mathrm{in} \mathrm{cells} \mathrm{and} \mathrm{secreted} \mathrm{LECT2} \mathrm{protein}$ in the culture medium were confirmed (Fig. 5A-B). Our results showed that overexpression

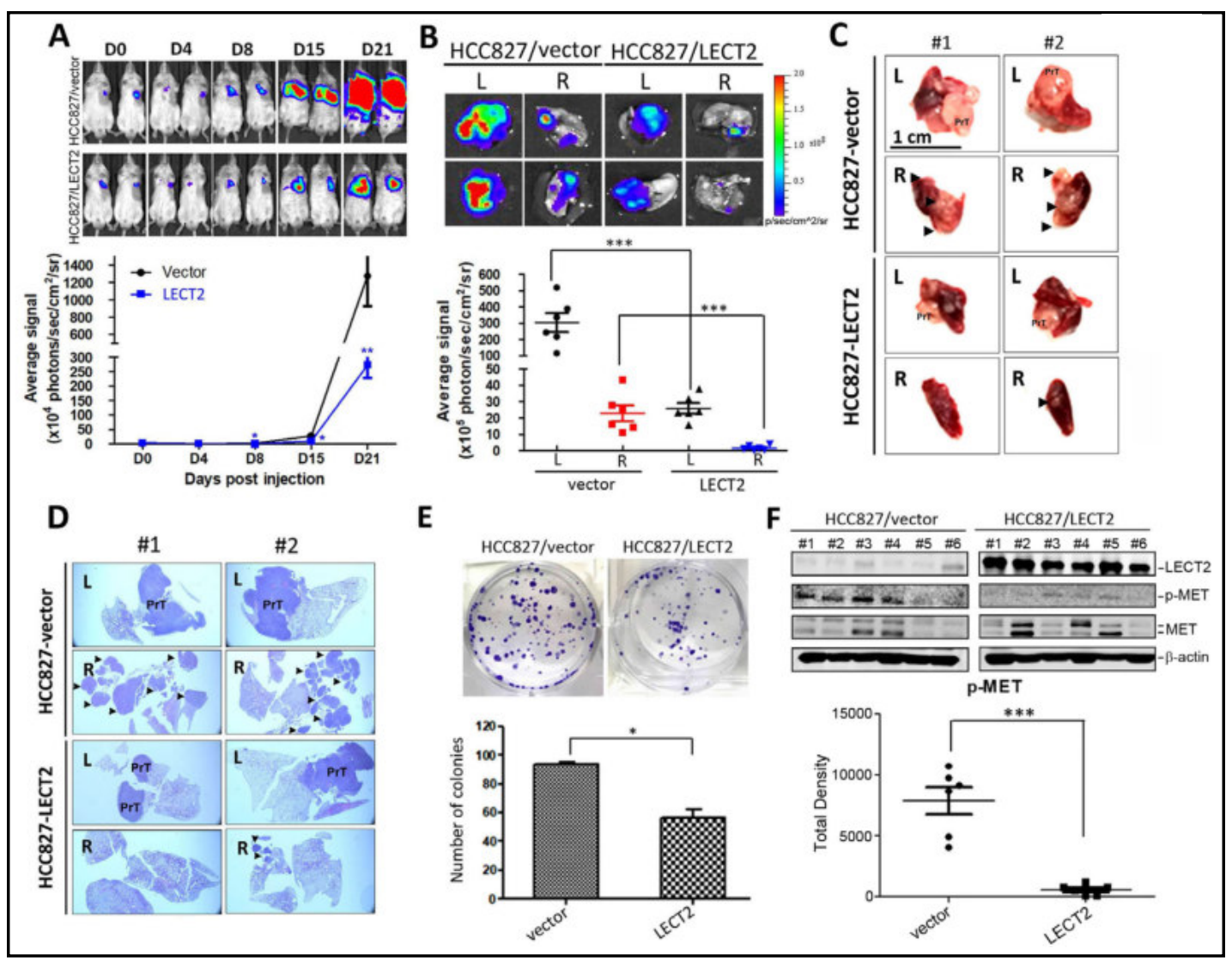

Fig. 7. Ectopic LECT2 expression suppresses growth and metastasis of a HCC827 orthotopic graft model by suppressing MET activation. Luciferase-tagged HCC827/LECT2 and HCC827/vector cells were orthotopically injected into NSG mice $(n=6)$. The tumor size was monitored by bioluminescence imaging. (A) Upper panel: Xenogen IVIS spectrum bioluminescence images of orthotopic lung tumor growth. A quantitative analysis of imaging signal intensity from tumor tissues on days $0,4,8,15$, and 21 after tumor implantation is shown in the lower panel. ${ }^{*} \mathrm{p}<0.05,{ }^{* *} \mathrm{p}<0.01$ compared to the control groups. (B-D) Lungs were isolated and examined at the end of this spontaneous metastasis assay. (B) Upper panel: Cancer metastasis from the left lung to the right lung was imaged with bioluminescence. Lower panel: Signal intensities from primary tumors (left lung) and metastatic tumors (right lung) were bioluminescently captured at the end of the study, with the mean signal for each group indicated. ${ }^{* * *} \mathrm{p}<0.001$ compared to the control group. (C) Representative pictures of lung tissues isolated from each group of mice, and metastatic colonies are indicated by an arrow in the right lungs. (D) H\&E staining of lungs and the metastatic colonies are indicated by an arrow in the right lungs. (E) Colony-forming abilities of HCC827 cells overexpressing LECT2 or control vector. Data are expressed as the mean \pm SD of three independent experiments. ${ }^{*} p<0.05$ compared to the control group. (F) HCC827/vector and HCC827/LECT2 orthotopic tumors were isolated for protein extraction at the end of the experiment, and a Western blot analysis was performed. Quantitative p-MET levels were respectively adjusted to MET and $\beta$-actin levels. Values are presented as the mean \pm SD. ${ }^{* * *} \mathrm{p}<0.001$ compared to the control group. 


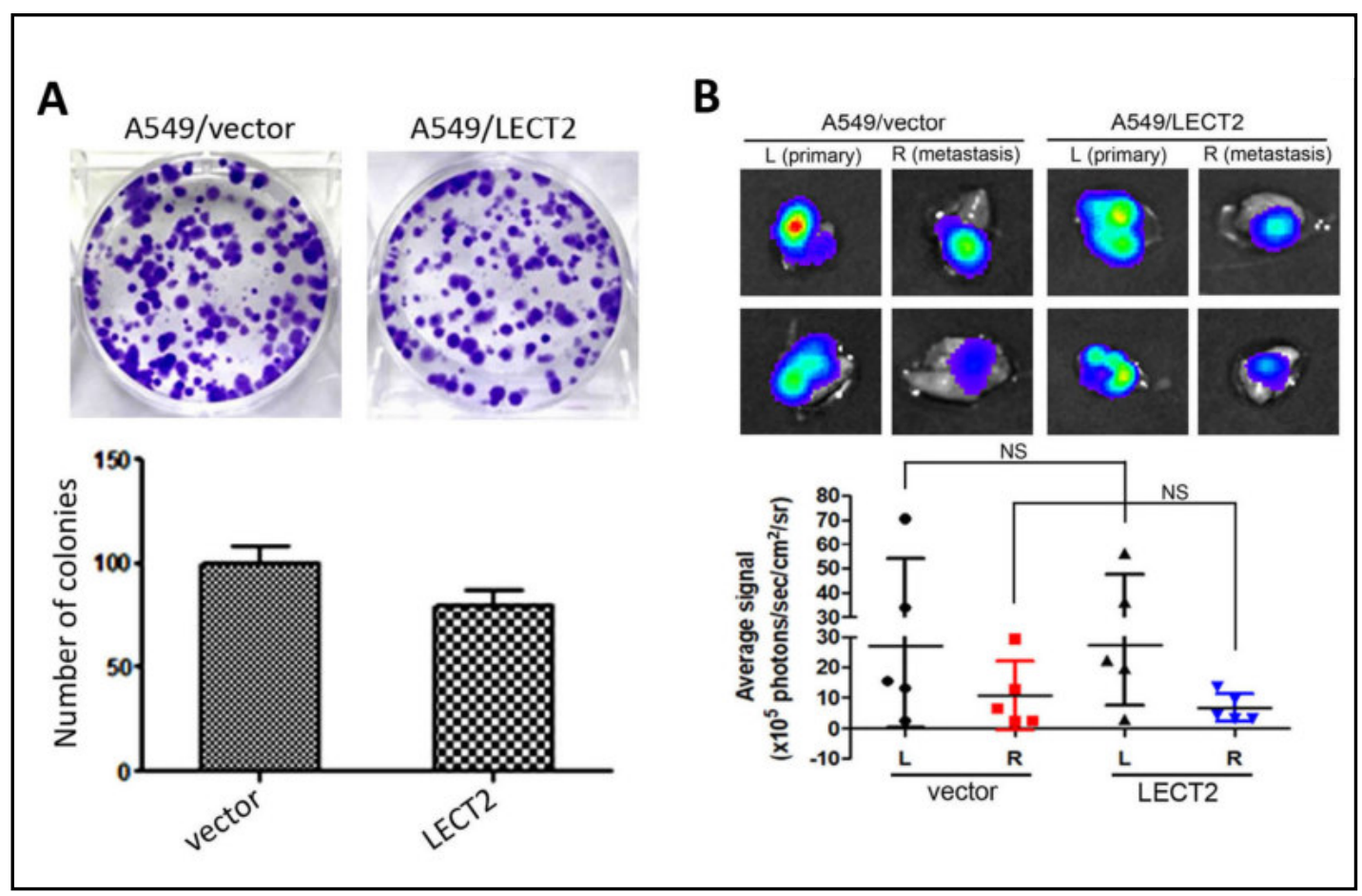

Fig. 8. LECT2 overexpression in A549 cells does not affect the in vitro colony-forming abilities and in vivo tumor progression. (A) Colony-forming abilities of A549 cells overexpressing LECT2 or control vector. Upper panel: Representative photomicrographs. Lower panel: Data are expressed as the mean \pm SD of three independent experiments. (B) Luciferase-tagged A549/LECT2 and A549/vector cells were injected into the left lateral thorax of NSG mice $(n=5)$. Upper panel: Primary tumor growth in the left lung and tumor metastasis in the right lung were imaged with bioluminescence at the end of the study. Lower panel: Signal intensities from primary tumors (left lung) and metastatic tumors (right lung) were bioluminescently captured, with the mean signal for each group indicated. NS, not significant.

of LECT2 significantly reversed HGF-induced MET activation in A549 cells and suppressed endogenous MET activity in HCC827 cells (Fig. 5C). Moreover, cells infected with pWPI-LECT2 showed inhibition of HGF-induced cell migration and invasion in A549 cell (Fig. 6A) and decreased basal migratory and invasive abilities in HCC827 cells (Fig. 6B). Taken together, our results suggest that LECT2 derived from the pWPI-LECT2 exhibited an autocrine or paracrine function.

Overexpression of LECT2 in orthotopic HCC827 xenografts in NOD-scid IL2r $\gamma^{\text {null }}$ (NSG) mice resulted in inhibition of tumor growth and metastasis by suppressing MET activation

To further elucidate the in vivo effects of LECT2 expression on human lung tumor progression, an orthotopic lung tumor-bearing model was established by transplanting luciferase-tagged cells, HCC827-luc or HCC827-luc/LECT2, into NSG mice. Three weeks after inoculation with cancer cells, the tumorigenic ability had decreased in LECT2-overexpressing HCC827 cells compared to control HCC827 cells (Fig. 7A). Moreover, after the mice were sacrificed, ex vivo imaging of their lungs showed a lower photon intensity in HCC827/ LECT2-injected mice compared to control mice, in both orthotopic tumors (left lung) and metastatic tumors (right lung) (Fig. 7B). Furthermore, mice bearing HCC827/LECT2 tumors also developed fewer metastatic nodules (as indicated by a black arrow) in the right lung compared to control mice (Fig. 7C). The histological data also confirmed the appearance of metastatic tumors in lung sections (as indicated by a black arrow) (Fig. 7D). Although our results showed that LECT2 only partially affected the proliferation rate of NSCLC cells in a short period of time (24 72 h) (Fig. 4), comparing the long-term culture (10 days) of 


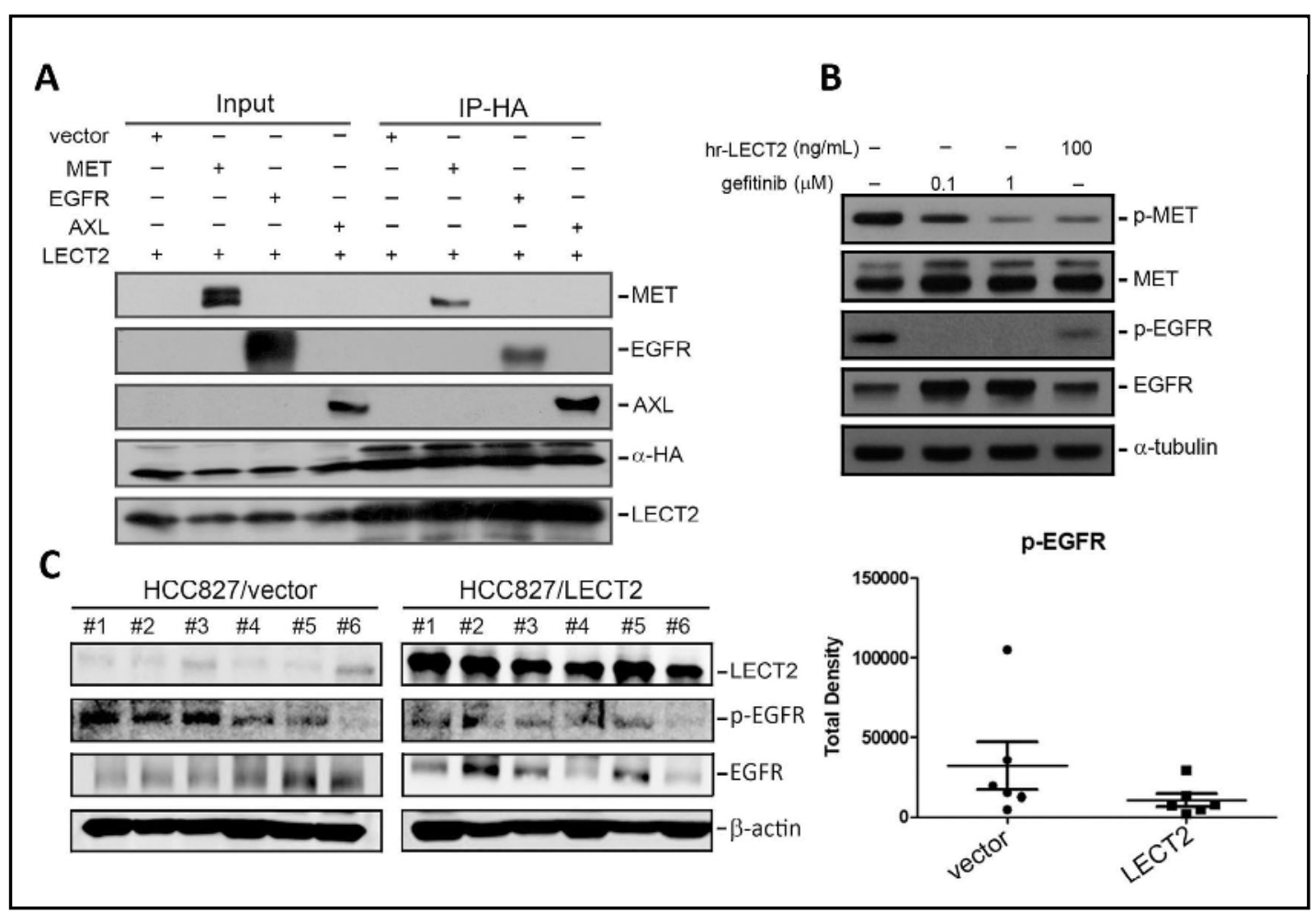

Fig. 9. LECT2 interacts with epidermal growth factor receptor (EGFR) to suppress its activation. (A) 293T cells were transfected with a hemoagglutinin (HA)-LECT2-expressing vector with the control vector, an EGFR-expressing vector, a MET-expressing vector, or an AXL-expressing vector as indicated. Cell lysates were immunoprecipitated with an HA antibody and then subjected to immunoblotting with the indicated antibodies. (B) Treatment of HCC827 cells with the vehicle, gefitinib ( 0.1 and $1 \mu \mathrm{M})$, or human recombinant (hr)-LECT2 (100 ng/mL) for $30 \mathrm{~min}$, and a Western blot analysis was performed to respectively detect phosphorylation levels of MET and EGFR. (C) HCC827/vector and HCC827/LECT2 orthotopic tumors were isolated for protein extraction at the end of the experiment and subjected to a Western blot analysis. Quantitative p-EGFR levels were respectively adjusted to EGFR and $\beta$-actin levels. Values are presented as the mean \pm SD.

HCC827/LECT2 to HCC827/vector cells, we found that overexpression of LECT2 significantly inhibited the colony-forming abilities (Fig. 7E). Next, we further detected LECT2 and p-MET protein levels of HCC827 xenografts harvested from LECT2-overexpressing or control mice and found that tumors from HCC827/LECT2-injected mice still retained high levels of LECT2, while levels of p-MET had decreased in tumors (Fig. 7F). In contrast to HCC827 cells, we found that LECT2 overexpression in A549 cells did not affect the in vitro colony-forming abilities or in vivo tumor progression (Fig. $8 \mathrm{~A}$ and B). Taken together, these data indicate that LECT2 overexpression suppressed the growth and metastatic abilities by inhibiting MET activation in an NSCLC xenograft model.

\section{EGFR, another important RTK involved in NSCLC progression, can be targeted and inhibited} by LECT2

Activating mutations in EGFR are commonly found in NSCLC and are important for the progression of NSCLC. According to previous studies, data from liquid chromatography/ tandem mass spectrometry (LC-MS/MS) showed that EGFR was also assumed to be bound by LECT2 [22]. We next tested whether LECT2 also inhibits EGFR phosphorylation through binding to EGFR. Co-IP experiments of 293T cells co-transfected with LECT2 and EGFR or MET revealed that LECT2 not only interacted with MET but also was associated with EGFR (Fig. 9A). Moreover, EGFR phosphorylation was markedly inhibited after hr-LECT2 


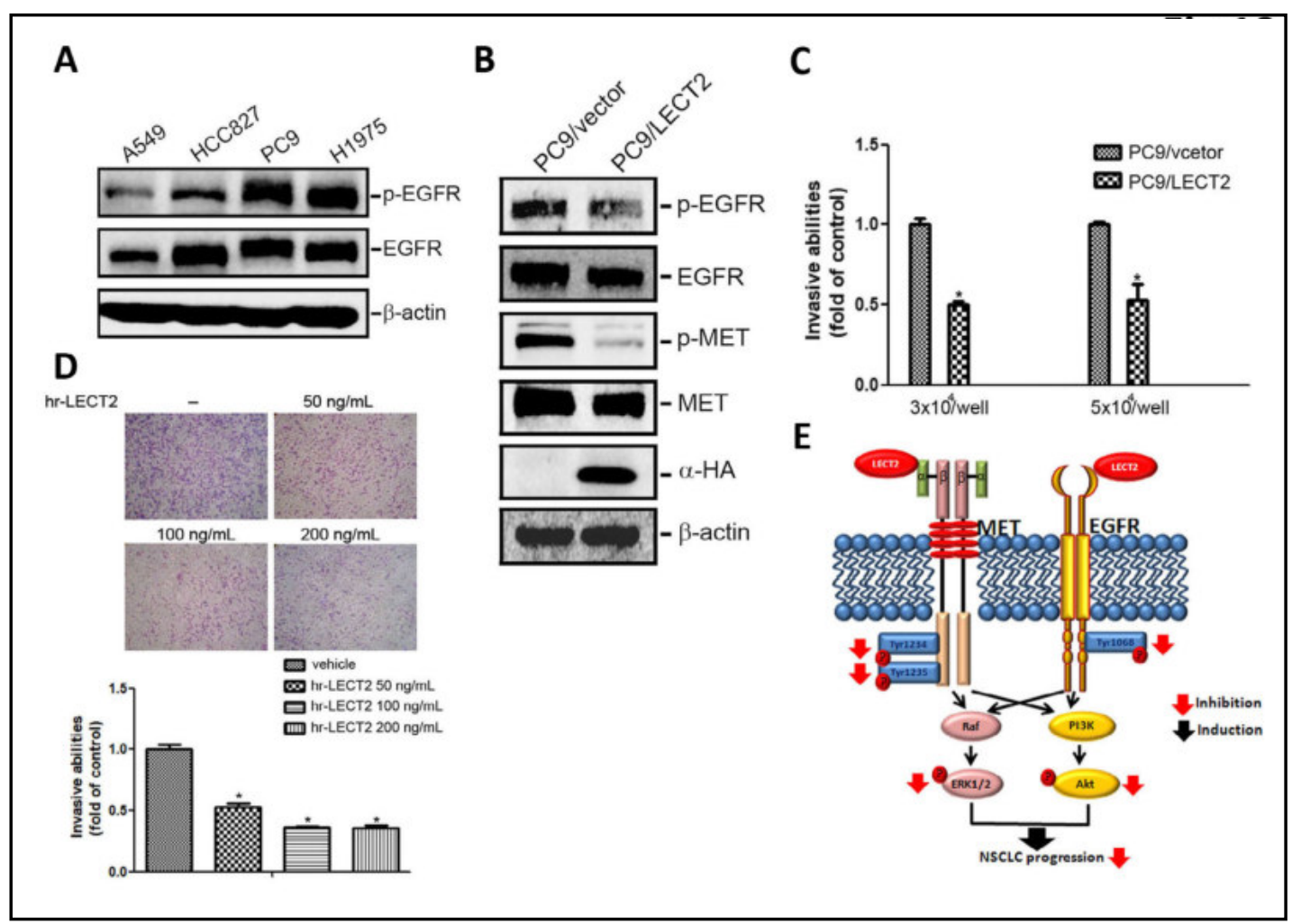

Fig. 10. LECT2 efficiently suppresses EGFR activation and motility in PC9 cells (A) Detection of protein levels of EGFR and p-EGFR by Western blotting in different non-small cell lung cancer (NSCLC) cell lines harboring WT (A549) and mutant EGFR (HCC827, PC9, and H1975). (B) Western blot analysis was used to detect MET and EGFR activation in PC9/vector and PC9/LECT2 cells. (C-D) PC9/LECT2 and PC9/vector cells at different seeding densities $\left(3 \times 10^{4} /\right.$ well and $5 \times 10^{4} /$ well) (C) or PC9 cells were treated with different concentrations of hr-LECT2 (50 200 ng/mL) for $24 \mathrm{~h}$ (D) were all subjected to a transwell Matrigel invasion assay. Results are expressed as multiples of the control. Data are expressed as the mean \pm SD of three independent experiments. ${ }^{*} \mathrm{p}<0.05$ compared to the control group. (E) Schematic diagram depicting the antitumor effects of LECT2 on NSCLC through binding with MET and EGFR to antagonize their activation and further suppress their common downstream pathways, PI3K/Akt and Raf-1/ERK1/2.

treatment in HCC827 cells (Fig. 9B). We further detected p-EGFR protein levels of HCC827 xenografts harvested from LECT2-overexpressing or control mice and found that LECT2 overexpression showed a decreasing trend of EGFR phosphorylation at orthotopic tumors sites (Fig. 9C). We further determined endogenous protein expression and activation levels of EGFR in other NSCLC cells and found that another EGFR-activating mutation cell, PC9, also harbored higher endogenous EGFR and MET activities compared to A549 cells (Fig. 3A, 10A). Similar to HCC827 cells, overexpressing LECT2 in PC9 cells significantly reduced EGFR and MET activation and suppressed the invasive ability of PC9 cells (Fig. 10B-C). Moreover, treatment of PC9 cells with different concentrations of hr-LECT2 also attenuated the invasive ability of cells (Fig. 10D). These data suggest that EGFR might be another target of LECT2 in suppressing progression of NSCLC cells. 


\section{Cellular Physiology Cell Physiol Biochem 2018:51:337-355 and Biochemistry Published \begin{tabular}{l|l} 
DOI: 10.1159/000495233 & $\begin{array}{l}\text { (c) } 2018 \text { The Author(s). Published by S. Karger AG, Basel } \\
\text { www.karger.com/cpb }\end{array}$
\end{tabular} \\ Hung et al.: LECT2 Retards NSCLC Progression via Targeting MET and EGFR}

\section{Discussion}

MET amplification is considered a mechanism of acquired resistance to EGFR-TKIs in NSCLC; therefore, combinations of EGFR and MET kinase inhibitors may lead to better therapeutic outcomes [27]. After treatment with EGFR-TKIs, up to 20\% of tumor samples presented MET protein overexpression or MET gene amplification. The MET gene mutation and the corresponding amplification of MET kinase occurred independently of the T790M status [28]. MET amplification was shown to restore the PI3K/Akt pathway mediated by ErbB3 transactivation and thereby induced acquired resistance to gefitinib [13]. In addition to MET amplification, Yano et al. determined that HGF-induced MET activation without a gene mutation or amplification could mediate activation of survival signaling (PI3K/Akt and ERK) independently of ErbB3 against gefitinib [9]. Moreover, Breindel et al. indicated that using gefitinib and U0126 respectively inhibited EGFR and ERK, which reduced MET activation in NSCLC cells harboring either the WT or mutant EGFR. Furthermore, MET signaling promoted EGFR-induced migration and invasion, and EGFR-MET signaling was enhanced in the highly metastatic PC9-BrM3 EGFR-mutant cell line, compared to the parental PC 9 line [29]. Overall, the results mentioned above all indicate that EGFR-MET signaling, including PI3K/Akt and ERK, is critical for the aggressive behavior of NSCLC. LECT2 was demonstrated to be a tumor suppressor in HCC [22], and serum LECT2 could be a potential biomarker in HCC patients [30]. However, it is not yet clear whether LECT2 also regulates the behaviors of NSCLC. In this study, we found that genetic depletion of LECT2 in mice and overexpression of LECT2 in NSCLC cells harboring mutant EGFR respectively promoted and suppressed progression (growth and metastasis) of cancer cells in xenograft mice models and in vitro cell models (migration, invasion, and colony formation). We subsequently generated recombinant murine and human LECT2 to investigate whether treatment with LECT2 would affect the behaviors of NSCLC cells and found that treatment of murine and human lung cancer cells with LECT2 suppressed cell motility and the colony-forming ability. These results imply that LECT2 functions as a circulating protein which affects NSCLC behaviors through paracrine effects. In addition to cancer, the circulating level of LECT2 was reported to be correlated with several pathologic conditions. For example, circulating LECT2 was positively correlated with the severity of both obesity and insulin resistance (IR) and was negatively correlated with the severity of sepsis in humans [20,31]. However, the correlation between circulating LECT2 and NSCLC prognoses should be further investigated in future work.

Mechanistic investigations showed that LECT2 treatment could enhance phagocytosis of macrophage via the CD209a receptor [32]. LECT2 can lead to IR in skeletal muscle cells by activating c-Jun N-terminal kinase (JNK) [31]. More recently, Hwang et al. showed that LECT2 induced an atherosclerotic inflammatory reaction via CD209-mediated JNK phosphorylation in human endothelial cells [33]. Our results showed that LECT2 can inhibit activation of both MET and EGFR and their common downstream pathways, Akt and ERK, to suppress tumorigenicity and metastasis of NSCLC. Moreover, co-IP data demonstrated that LECT2 directly interacts with MET and EGFR. Previous studies indicated that LECT2 bound to the extracellular domain of MET and did not compete with HGF for the MET receptor. LECT2 was reported to induce an association between PTP-1B and MET to suppress MET activation [22]. PTP-1B as well as other PTPs, such as receptor type of protein tyrosine phosphatase sigma (RPTPo), LAR, Src homology region 2 domain-containing phosphatase (SHP)-1, and T-cell protein tyrosine phosphatase (TCPTP), were implicated in the dephosphorylation of the EGFR and consequent suppression of EGFR signaling [34]. At present, our results only showed that LECT2 can bind to EGFR and further inhibit EGFR activation. However, the binding site of LECT2 on EGFR and the effect of LECT2 on PTPs should be further investigated.

Interestingly, from the results of the in vitro colony-forming ability and in vivo tumor xenograft assay, we found that the malignant phenotype of cells harboring activated MET and EGFR (HCC827 and PC9 cells) could be suppressed by LECT2, but cells lacking constitutive activation of MET and EGFR (A549 cells) were not affected by LECT2. These results suggest that dual inhibition of EGFR/MET pathways might be critical for the ability of LECT2 to inhibit 


\section{Cellular Physiology Cell Physiol Biochem 2018:51:337-355

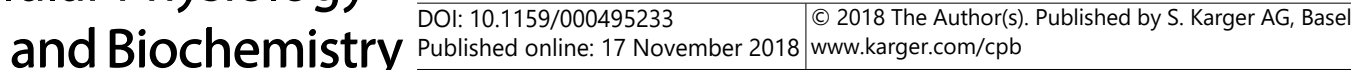 \\ Hung et al.: LECT2 Retards NSCLC Progression via Targeting MET and EGFR}

NSCLC progression. Moreover, our study results showed that the growth inhibitory effect of LECT2 against HCC827 xenografts was more dominant than its effect against the colonyforming ability of HCC827 cells, suggesting that LECT2 might target tumor cells and also affect the lung tumor microenvironment. Actually, previous studies indicated that LECT2 can target vascular endothelial growth factor receptor 2 (VEGFR2) of human endothelial cells to show an antiangiogenic effect [35]. Angiogenesis is essential for the processes of primary tumor growth and metastasis of NSCLC [36]. In addition to endothelial cells, LECT2 was also reported to activate macrophages, resulting in increased phagocytic activity and cytokine expressions such as interferon (IFN)- $\gamma$ and the chemokine INF- $\gamma$-inducible protein $10 \mathrm{kDa}$ (CXCL-10) [32]. In a xenograft model of lung adenocarcinoma, the production of CXCL10 was inversely correlated with tumor growth, resulting in a marked reduction in tumorassociated angiogenesis [37, 38]. IFN- $\gamma$ was shown to be involved in the antiproliferative, antiangiogenic, and proapoptotic effects against cancer cells [39]. Taken together, the angiostatic effect of LECT2 may be partly attributable to its capacity to suppress lung tumor progression in vivo. Alveolar macrophages (AMs) are likely to be of central importance in the lung cancer immune response. A dual role of macrophages in lung cancer was suggested with the idea that AMs may both inhibit and/or promote tumor progression [40]. There are two different types of macrophages, including classical M1 and alternative M2 macrophages, which respectively exhibit antitumor and protumor effects. M1 macrophages are activated by IFN- $\gamma$ treatment, while the M1 macrophage subset was associated more within tumor islets and with extended survival times in patients with NSCLC [41]. The effects of LECT2 on the polarization of AMs, cytokine secretion from AMs, and phagocytic activity of AMs are worthy of investigation in the future.

\section{Conclusion}

The present data fist demonstrated that LECT2 is a potential therapeutic agent for NSCLC because it inhibits activation of both EGFR and MET and their common downstream signaling pathways, PI3K/Akt and Raf-1/ERK1/2, which are important in promoting NSCLC progression (Fig. 10E). Resistance of NSCLC cells to gefitinib treatment was mediated by MET activation [13]. In addition to MET, AXL, another RTK, was recently reported to contribute to the survival of EGFR-mutant lung cancer cells in a manner similar to that observed for MET [42]. High activation of AXL was observed in NSCLC cells with acquired resistance to erlotinib treatment, and increased AXL expression was found in approximately $20 \%$ of patients with acquired resistance to EGFR-TKIs [43]. Interestingly, the LC-MS/MS data from a previous study [22] and the Co-IP data from the present study showed that LECT2 also interacted with AXL (Fig. 9A). Although the effect of LECT2 on AXL activation in NSCLC cells remains unknown, our present findings still support the development of clinical trials to determine whether LECT2 or LECT2 combined with other TKI regimens would be useful in managing human NSCLC, especially NSCLC cells that have acquired resistance to EGFR-TKIs harboring the MET amplification.

\section{Acknowledgements}

We would like to thank Dr. Shuang-En Chuang (National Health Research Institutes, Taiwan) for the gift of the AXL-overexpressing plasmid. We also thank Dr. Yen-Kuang Lin (Biostatistics Center, College of Management, Taipei Medical University, Taipei, Taiwan) for the assistance in statistical analysis. This study was supported by grant 107TMU-WFH-13 from Wan Fang Hospital, Taipei Medical University. This study was also supported by the "TMU Research Center of Cancer Translational Medicine" from The Featured Areas Research Center Program within the framework of the Higher Education Sprout Project by the Ministry of Education (MOE) in Taiwan. 


\section{Cellular Physiology Cell Physiol Biochem 2018;51:337-355

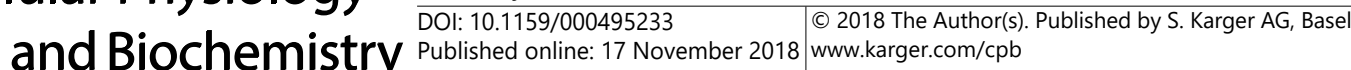

\section{Disclosure Statement}

All authors declare that they have no conflicts of interest.

\section{References}

1 Bareschino MA, Schettino C, Rossi A, Maione P, Sacco PC, Zeppa R, Gridelli C: Treatment of advanced non small cell lung cancer. J Thorac Dis 2011;3:122-133.

2 Fu XL, Zhu XZ, Shi DR, Xiu LZ, Wang LJ, Zhao S, Qian H, Lu HF, Xiang YB, Jiang GL: Study of prognostic predictors for non-small cell lung cancer. Lung Cancer 1999;23:143-152.

3 Group NM-AC: Chemotherapy in addition to supportive care improves survival in advanced non-smallcell lung cancer: a systematic review and meta-analysis of individual patient data from 16 randomized controlled trials. J Clin Oncol 2008;26:4617-4625.

4 Husain H, Scur M, Murtuza A, Bui N, Woodward B, Kurzrock R: Strategies to Overcome Bypass Mechanisms Mediating Clinical Resistance to EGFR Tyrosine Kinase Inhibition in Lung Cancer. Mol Cancer Ther 2017;16:265-272.

5 Morgillo F, Della Corte CM, Fasano M, Ciardiello F: Mechanisms of resistance to EGFR-targeted drugs: lung cancer. ESMO Open 2016;1:e000060.

6 Jazieh AR, Al Sudairy R, Abu-Shraie N, Al Suwairi W, Ferwana M, Murad MH: Erlotinib in wild type epidermal growth factor receptor non-small cell lung cancer: A systematic review. Ann Thorac Med 2013;8:204-208.

-7 Ettinger DS, Akerley W, Bepler G, Blum MG, Chang A, Cheney RT, Chirieac LR, D’Amico TA, Demmy TL, Ganti AK, Govindan R, Grannis FW., Jr, Jahan T, Jahanzeb M, Johnson DH, Kessinger A, Komaki R, Kong FM, Kris MG, Krug LM et al.: Non-small cell lung cancer. J Natl Compr Canc Netw 2010;8:740-801.

8 Xu J, Ding G, Zhang X, Jin B, Lou Y, Zhang Y, Wang H, Wu D, Han B: The EGFR tyrosine kinase inhibitors as second-line therapy for EGFR wild-type non-small-cell lung cancer: a real-world study in People's Republic of China. Onco Targets Ther 2016;9:6479-6484.

-9 Yano S, Wang W, Li Q, Matsumoto K, Sakurama H, Nakamura T, Ogino H, Kakiuchi S, Hanibuchi M, Nishioka Y, Uehara H, Mitsudomi T, Yatabe Y, Nakamura T, Sone S: Hepatocyte growth factor induces gefitinib resistance of lung adenocarcinoma with epidermal growth factor receptor-activating mutations. Cancer Res 2008;68:9479-9487.

10 Sierra JR, Tsao MS: c-MET as a potential therapeutic target and biomarker in cancer. Ther Adv Med Oncol 2011;3:S21-35.

11 Jung KH, Park BH, Hong SS: Progress in cancer therapy targeting c-Met signaling pathway. Arch Pharm Res 2012;35:595-604.

12 Masuya D, Huang C, Liu D, Nakashima T, Kameyama K, Haba R, Ueno M, Yokomise H: The tumour-stromal interaction between intratumoral c-Met and stromal hepatocyte growth factor associated with tumour growth and prognosis in non-small-cell lung cancer patients. Br J Cancer 2004;90:1555-1562.

13 Engelman JA, Zejnullahu K, Mitsudomi T, Song Y, Hyland C, Park JO, Lindeman N, Gale CM, Zhao X, Christensen J, Kosaka T, Holmes AJ, Rogers AM, Cappuzzo F, Mok T, Lee C, Johnson BE, Cantley LC, Janne PA: MET amplification leads to gefitinib resistance in lung cancer by activating ERBB3 signaling. Science 2007;316:1039-1043.

14 Tanizaki J, Okamoto I, Sakai K, Nakagawa K: Differential roles of trans-phosphorylated EGFR, HER2, HER3, and RET as heterodimerisation partners of MET in lung cancer with MET amplification. Br J Cancer 2011;105:807-813.

15 Yang H, Wang R, Peng S, Chen L, Li Q, Wang W: Hepatocyte growth factor reduces sensitivity to the epidermal growth factor receptor-tyrosine kinase inhibitor, gefitinib, in lung adenocarcinoma cells harboring wild-type EGFR. Oncotarget 2016;7:16273-16281.

-16 Spigel DR, Ervin TJ, Ramlau RA, Daniel DB, Goldschmidt JH, Jr., Blumenschein GR, Krzakowski MJ, Robinet G, Godbert B, Barlesi F, Govindan R, Patel T, Orlov SV, Wertheim MS, Yu W, Zha J, Yauch RL, Patel PH, Phan SC, Peterson AC: Randomized phase II trial of Onartuzumab in combination with erlotinib in patients with advanced non-small-cell lung cancer. J Clin Oncol 2013;31:4105-4114. 


\section{Cellular Physiology Cell Physiol Biochem 2018;51:337-355 and Biochemistry \begin{tabular}{l|l} 
DOI: $10.1159 / 000495233$ \\
(c) 2018 The Author(s). Published by S. Karger AG, Basel
\end{tabular}

Hung et al.: LECT2 Retards NSCLC Progression via Targeting MET and EGFR

17 Yamagoe S, Yamakawa Y, Matsuo Y, Minowada J, Mizuno S, Suzuki K: Purification and primary amino acid sequence of a novel neutrophil chemotactic factor LECT2. Immunol Lett 1996;52:9-13.

18 Comenzo RL: LECT2 makes the amyloid list. Blood 2014;123:1436-1437.

19 Saito T, Okumura A, Watanabe H, Asano M, Ishida-Okawara A, Sakagami J, Sudo K, Hatano-Yokoe Y, Bezbradica JS, Joyce S, Abo T, Iwakura Y, Suzuki K, Yamagoe S: Increase in hepatic NKT cells in leukocyte cell-derived chemotaxin 2-deficient mice contributes to severe concanavalin A-induced hepatitis. J Immunol 2004;173:579-585.

20 Ando K, Kato H, Kotani T, Ozaki M, Arimura Y, Yagi J: Plasma leukocyte cell-derived chemotaxin 2 is associated with the severity of systemic inflammation in patients with sepsis. Microbiol Immunol 2012;56:708-718.

-21 Ong HT, Tan PK, Wang SM, Hian Low DT, Ooi LL, Hui KM: The tumor suppressor function of LECT2 in human hepatocellular carcinoma makes it a potential therapeutic target. Cancer Gene Ther 2011;18:399406.

22 Chen CK, Yang CY, Hua KT, Ho MC, Johansson G, Jeng YM, Chen CN, Chen MW, Lee WJ, Su JL, Lai TC, Chou CC, Ho BC, Chang CF, Lee PH, Chang KJ, Hsiao M, Lin MT, Kuo ML: Leukocyte cell-derived chemotaxin 2 antagonizes MET receptor activation to suppress hepatocellular carcinoma vascular invasion by protein tyrosine phosphatase 1B recruitment. Hepatology 2014;59:974-985.

23 Andres SA, Bickett KE, Alatoum MA, Kalbfleisch TS, Brock GN, Wittliff JL: Interaction between smoking history and gene expression levels impacts survival of breast cancer patients. Breast Cancer Res Treat 2015; 152:545-556.

-24 Lee YC, Saijo N, Sasaki Y, Takahashi H, Sakurai M, Ishihara J, Hoshi A, Chen KM, Hamburger AW: Clonogenic patterns of human pulmonary adenocarcinoma cell lines (PC-9, PC-13 and PC-14) and how they influence the results of test for chemosensitivity to cisplatin in the human tumor clonogenic assay. Jpn J Clin Oncol 1985;15:637-644.

25 Lee WJ, Hsiao M, Chang JL, Yang SF, Tseng TH, Cheng CW, Chow JM, Lin KH, Lin YW, Liu CC, Lee LM, Chien MH: Quercetin induces mitochondrial-derived apoptosis via reactive oxygen species-mediated ERK activation in HL-60 leukemia cells and xenograft. Arch Toxicol 2015;89:1103-1117.

-26 Li A, Gao HF, Wu YL: Targeting the MET pathway for potential treatment of NSCLC. Expert Opin Ther Targets 2015;19:663-674.

27 Brugger W, Thomas M: EGFR-TKI resistant non-small cell lung cancer (NSCLC): new developments and implications for future treatment. Lung Cancer 2012;77:2-8.

28 Bean J, Brennan C, Shih JY, Riely G, Viale A, Wang L, Chitale D, Motoi N, Szoke J, Broderick S, Balak M, Chang WC, Yu CJ, Gazdar A, Pass H, Rusch V, Gerald W, Huang SF, Yang PC, Miller V, Ladanyi M, Yang CH, Pao W: MET amplification occurs with or without T790M mutations in EGFR mutant lung tumors with acquired resistance to gefitinib or erlotinib. Proc Natl Acad Sci U S A 2007;104:20932-20937.

-29 Breindel JL, Haskins JW, Cowell EP, Zhao M, Nguyen DX, Stern DF: EGF receptor activates MET through MAPK to enhance non-small cell lung carcinoma invasion and brain metastasis. Cancer Res 2013;73:50535065.

-30 Okabe H, Delgado E, Lee JM, Yang J, Kinoshita H, Hayashi H, Tsung A, Behari J, Beppu T, Baba H, Monga SP: Role of leukocyte cell-derived chemotaxin 2 as a biomarker in hepatocellular carcinoma. PLoS One 2014;9:e98817.

-31 Lan F, Misu H, Chikamoto K, Takayama H, Kikuchi A, Mohri K, Takata N, Hayashi H, Matsuzawa-Nagata N, Takeshita Y, Noda H, Matsumoto Y, Ota T, Nagano T, Nakagen M, Miyamoto K, Takatsuki K, Seo T, Iwayama K, Tokuyama K et al.: LECT2 functions as a hepatokine that links obesity to skeletal muscle insulin resistance. Diabetes 2014;63:1649-1664.

-32 Lu XJ, Chen J, Yu CH, Shi YH, He YQ Zhang RC, Huang ZA, Lv JN, Zhang S, Xu L: LECT2 protects mice against bacterial sepsis by activating macrophages via the CD209a receptor. J Exp Med 2013;210:5-13.

-33 Hwang HJ, Jung TW, Hong HC, Seo JA, Kim SG, Kim NH, Choi KM, Choi DS, Baik SH, Yoo HJ: LECT2 induces atherosclerotic inflammatory reaction via CD209 receptor-mediated JNK phosphorylation in human endothelial cells. Metabolism 2015; 64:1175-1182.

-34 Tiganis T: Protein tyrosine phosphatases: dephosphorylating the epidermal growth factor receptor. IUBMB Life 2002;53:3-14. 


\section{Cellular Physiology Cell Physiol Biochem 2018;51:337-355

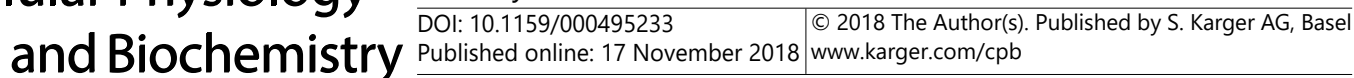

Hung et al.: LECT2 Retards NSCLC Progression via Targeting MET and EGFR

-35 Chen CK, Yu WH, Cheng TY, Chen MW, Su CY, Yang YC, Kuo TC, Lin M T, Huang YC, Hsiao M, Hua KT, Hung MC, Kuo ML: Inhibition of VEGF165/VEGFR2-dependent signaling by LECT2 suppresses hepatocellular carcinoma angiogenesis. Sci Rep 2016;6:31398.

-36 Hall RD, Le TM, Haggstrom DE, Gentzler RD: Angiogenesis inhibition as a therapeutic strategy in non-small cell lung cancer (NSCLC). Transl Lung Cancer Res 2015;4:515-523.

-37 Arenberg DA, White ES, Burdick MD, Strom SR, Strieter RM: Improved survival in tumor-bearing SCID mice treated with interferon-gamma-inducible protein 10 (IP-10/CXCL10). Cancer Immunol Immunother 2001;50:533-538.

38 Rivas-Fuentes S, Salgado-Aguayo A, Pertuz Belloso S, Gorocica Rosete P, Alvarado-Vasquez N, AquinoJarquin G: Role of Chemokines in Non-Small Cell Lung Cancer: Angiogenesis and Inflammation. J Cancer 2015;6:938-952.

39 Zaidi MR, Merlino G: The two faces of interferon-gamma in cancer. Clin Cancer Res 2011;17:6118-6124.

-40 Almatroodi SA, McDonald CF, Pouniotis DS: Alveolar Macrophage Polarisation in Lung Cancer. Lung Cancer Int 2014;2014:721087.

41 Ohri CM, Shikotra A, Green RH, Waller DA, Bradding P: Macrophages within NSCLC tumour islets are predominantly of a cytotoxic M1 phenotype associated with extended survival. Eur Respir J 2009;33:118126.

42 Zhang Z, Lee JC, Lin L, Olivas V, Au V, LaFramboise T, Abdel-Rahman M,Wang X, Levine AD, Rho JK, Choi YJ, Choi CM, Kim SW, Jang SJ, Park YS, Kim WS, Lee DH, Lee JS, Miller VA, Arcila M, et al.: Activation of the AXL kinase causes resistance to EGFR-targeted therapy in lung cancer. Nat Genet 2012;44:852-860.

43 Rho JK, Choi YJ, Kim SY, Kim TW, Choi EK, Yoon SJ, Park BM, Park E, Bae JH, Choi CM, Lee JC: MET and AXL inhibitor NPS-1034 exerts efficacy against lung cancer cells resistant to EGFR kinase inhibitors because of MET or AXL activation. Cancer Res 2014;74:253-262. 